\title{
Interaction of cyanine dyes with nucleic acids. I. Studies on monomethyne cyanine dyes as possible fluorescent probes for the detection of nucleic acids
}

\author{
Sergiy M. Yarmoluk*, Alexander N. Zhyvoloup ${ }^{1}$, Vladyslava B. Koval'ska, \\ Ilona V. Klimenko, Alexander P. Kukharenko, Yuriy P. Kovtun ${ }^{2}$, \\ Yuriy L. Slominsky ${ }^{2}$ \\ Institute of Molecular Biology and Genetics, Nat. Acad. Sci. of Ukraine, \\ 150 7abolotnogo str., Kyiv, Ukraine, 252143 \\ 'Institute of Cell Biology and Genetic Engineering, Nat. Acad. Sci. of Ukraine, \\ 148 Zabolotnogo str., Kyiv, Úkraine, 252143 \\ ${ }^{2}$ Institute of Organic Chemistry, Nat. Acad. Sci. of Ukraine, \\ 5 Mourmanska str., Kyiv, Ukraine, 252660
}

\begin{abstract}
The series of monomethyne cyanine dyes as possible fluorescent probes for DNA and RNA analysis were synthesized and their optical properties were studied. Two dyes interacted with native DNA and RNA with strong fluorescence enhancement (up to 350 and 1550 times for $C$ yan 3 and $C$ yan 6 , respectively). The complex of $C$ yan 4 with nucleic acids had -rtremely large Stokes shift $(154 \mathrm{~nm})$. Methylenoxybenzthiazole residue seems to be perspective structural fragment for the synthes is of new nucleic acid binding cyanine dyes.
\end{abstract}

Introduction. Recent years cyanine dyes becarne the object of extensive studies with potential of application for detection of nucleic acids. Asymmetrical monomethyne cyanines are virtually nonfluorescent in free state, but show very strong fluorescence when complexed with nucleic acids. Lee et al. showed that monointercalator Thiazole Orange (TO, 4-13-methyl-2,3-dihydro-(benzo-1,3thiazole)-methyl-ilydene-quinolinium iodide) formed complexes with RNA with 3000-fold enhancement of fluorescence upon binding [1].

Rye with co-workers reproduced results of Lee and synthesized two ncw dineric cyanine dyes: bis-thiazole orange (TOTO; 1,1'-(4, 4, 7, 7-tetramethyl4, 7-diazaundeca-methylene)-bis-4-[3-methyl-2, 3-dihydro-(benzo-1, 3-thiazole) -2-methyl-ilydene ]-quinolinum tetraiodide) and bis-yellow orange (YOYO; an analogue of TOTO with a benzo-1,3-oxazole instead of benzo-1,3-thiazole). They revealed that TOTO and YOYO form very stable complexes with double-stranded DNA with up to 1000 fold fluorescence enhancement [2].

For TOTO and YOYO bis-intercalation mode with ratio 1 dye per 5 base pairs was proposed $[2,41$.

It may secmed obvious from results presented in [3] to conclude that polycationic nature of biscyanine dyes complicates proposed intercalation as mechanism of interaction.

The selective binding of TOTO to the CTGA:TCAG site of oligonucleotides was demonstrated [5].

\footnotetext{
*Correspondence address.

(C) S. M. YAKMOIIK, A N. ZHYYOLOLP, $Y$. B. KOYALSKA. I. V. KLLMENKO, A. P. KUKHARENKO Yi. P. KOYTUN, Yu. L. SLOMINSKY, 1990
} 
In this article investigations of a series of cyanine dyes with different chemical structures and their optical properties in free and NA-bound state, are presented. It was shown that two of such compounds, Cyan 3 and Cyan 6 (see Table 1, for structures) form highly fluorescent complexes both with DNA and RNA. It was considered that methylenoxybenzthiazole fragment can be used for design of new NA-binding cyanine dyes.

Materials and Methods. The absorption spectra were recorded on «SPECORD UV-VIS» spectrophotometer (Germany). Absorption of free dyes was measured immediately after dissolving DMSO dye stock solution in appropriate solvents: $50 \mathrm{mM}$ Tris-HCl, pH 8; octanol (Sigma); DMSO (Sigma).

The emission spectra of free dyes and dye/nucleic acids complexes were recorded on HITACHI Model 850 fluorescent spectrophotometer (Japan). Fluorescence measurements were carried out in a thermostated quartz cell ( $1 \mathrm{x}$ x $1 \mathrm{~cm}$ ). Fluorescence was excited with a $150 \mathrm{~W}$ Xe-lamp emission.

Synthesis of cyanine dyes. Dyes were synthesized according to methods described in [6] and their purity was analysed by NMR and HPLC.

Preparation of DNA, RNA and dyes solutions. Stock solutions of dyes $(1 \mathrm{mg} / \mathrm{ml}$ ) were prepared by dissolving of the dyes in DMSO. All the dyes were

Table I

Optical propertics of dyes

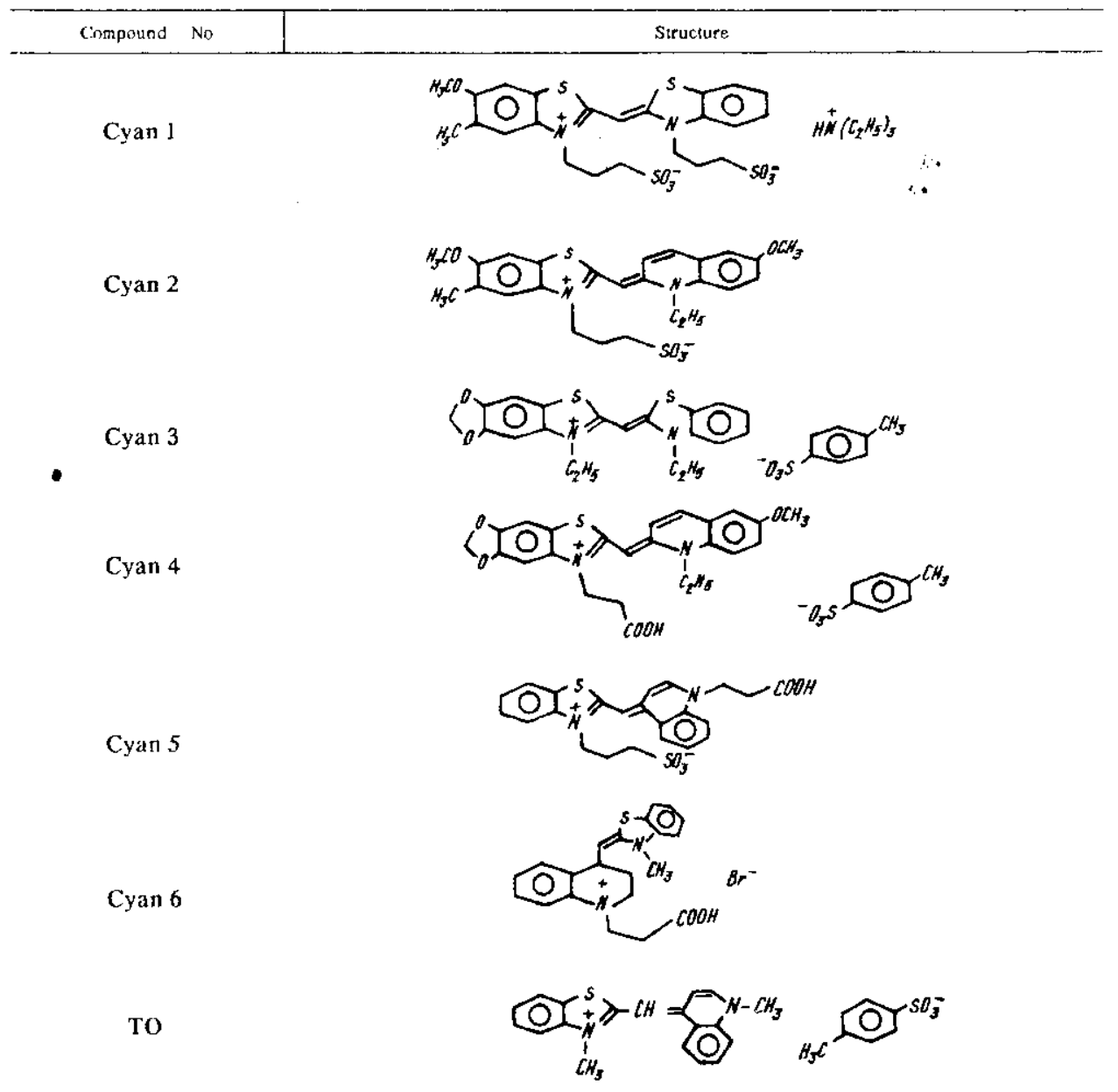

$\mathrm{H}_{2} \mathrm{O}=50 \mathrm{mM}$ Tris-HCl, pH 8.0; ${ }^{* 4}$ the extinction values for dyes in water are subject to some are not detected under used dye concentration. 
stable under these conditions for several months, whereas in aqueous solutions some dyes gradually lose their fluorescent properties. Working solutions were prepared immediately prior to use.

For spectral studies total calf thymus DNA (Sigma) and yeast RNA (Sigma) were used. Nucleic acids solutions were prepared in TE buffer $(10 \mathrm{mM}$ Tris- $\mathrm{HCl}$, EDTA $0.5 \mathrm{mM}, \mathrm{pH} 8$ ) with concentration $4 \mathrm{mg} / \mathrm{ml}$ and $8 \mathrm{mg} / \mathrm{ml}$ for DNA and RNA, respectively.

Absorbance and fluorescent emission spectra. For spectral measurements the complexes of dyes with nucleic acids were prepared by adding dye stock solution and DNA or RNA solution in Tris- $\mathrm{HCl} 50 \mathrm{mM}, \mathrm{pH} 8.0$ buffer. The final concentration of DNA was $0.48 \mathrm{mM}$ and of RNA $0.46 \mathrm{mM}$. Final dyes concentrations were $0.02 \mathrm{mM}$. Absorbtion and emission spectra of dye-nucleic acid complexes were measured at approximate ratio 1 dye per 25 base pairs.

For optical measurements of free cyanines the same dyes concentrations were used.

Results. Dye structures and spectroscopic properties of free dyes. Physical data for seven synthesized cyanine dyes are presented in Table 1. The fluorescent and absorbance properties of these dyes have not been previously

\begin{tabular}{|c|c|c|c|c|c|}
\hline Solven 1 & $10^{4}, \mathrm{M}^{-1} \mathrm{~cm}^{-1}$ & ${ }^{a d s} \lambda_{\max }{ }^{* *}, \quad$ nm & ${ }^{e m_{\lambda}} \max , \quad \mathrm{nm}$ & $\Delta S, \quad$ nsm & $\phi \cdot 10^{-2} \quad\left(\mathrm{H}_{2} \mathrm{O}\right)$ \\
\hline $\mathrm{H}_{2} \mathrm{O}^{*}$ & - & 417,439 & 507 & 76 & 1.16 \\
\hline DMSO & 1.92 & -442 & 491 & 49 & - \\
\hline Octanol & - & -440 & 490 & 50 & - \\
\hline $\mathrm{H}_{2} \mathrm{O}$ & - & -481 & n.d & n.d & n.d \\
\hline DMSO & 3.10 & -509 & n.d & n.d & - \\
\hline Octanol & - & -500 & 560 & 60 & - \\
\hline $\mathrm{H}_{2} \mathrm{O}$ & - & 420,439 & 518 & 79 & 0.44 \\
\hline DMSO & 6.31 & -440 & 508 & 68 & $\rightarrow$ \\
\hline Octanol & - & -440 & 504 & 64 & - \\
\hline $\mathrm{H}_{2} \mathrm{O}$ & - & 370,485 & n.d & n.d & n.d \\
\hline DMSO & 3.36 & $-\quad 525$ & 564 & 44 & - \\
\hline Octanol & - & -518 & n.d & n.d & - \\
\hline $\mathrm{H}_{2} \mathrm{O}$ & - & 483,510 & n.d & n.d & n.d \\
\hline DMSO & 6.35 & -512 & n.d & n.d & - \\
\hline Octanol & - & -502 & 560 & 58 & - \\
\hline $\mathrm{H}_{2} \mathrm{O}$ & $一$ & 483,510 & n.d & 76 & n.d \\
\hline DMSO & 4.96 & -512 & n.d & 49 & - \\
\hline Octanol & - & -500 & n.d & 50 & - \\
\hline $\mathrm{H}_{2} \mathrm{O}$ & - & 481,505 & n.d & n.d & n.d \\
\hline DMSO & 7.70 & -510 & n.d & n.d & - \\
\hline Octanol & - & -500 & n.d & n.d & - \\
\hline
\end{tabular}

error because of the tendency to form dye associates even at the low concentration; $n$. $d$. - values 
studied. Dye TO with well known spectral properties [1] was included for comparison. The wavelengths of absorbtion maxima $\left(\lambda^{\text {abs }}\right)$ of different dyes range over $100 \mathrm{~nm}$ and slightly depend on solvent. Absorption maxima of the dyes showed the red shift of 1-29 $\mathrm{nm}$ after going from water to the less polar solvents: DMSO, octanol. The extinction coefficient for all the dyes are high, about $1 \cdot 10^{4}$.

Since the fluorescence of free dyes is very low, the wavelengths of emission maxima $\left(\lambda^{\mathrm{em}}\right)$ and quantum yields at used concentrations were determined only for Cyan 1 and Cyan 3. All of these dyes have Stokes shift between 40 and 79 $\mathrm{nm}$.

The NA-interaction properties of dyes. The data on the absorbance and fluorescence emission spectra of the NA-bound form of dyes are presented in Table 2.

The most dyes had short Stokes shifts $(14-68 \mathrm{~nm})$, which resulted in overlap of the excitation and cmission spectra. Cyan 4 had the largest Stokes

Table 2

Optical properties of Dye/NA complexes

\begin{tabular}{|c|c|c|c|c|c|c|c|c|}
\hline \multirow{2}{*}{$\begin{array}{c}\text { Compound } \\
\text { No }\end{array}$} & \multicolumn{4}{|c|}{ DNA } & \multicolumn{4}{|c|}{ RNA } \\
\hline & ${ }^{a b s} \lambda_{\text {tmax }}, \quad$ nm & $\mathrm{em}_{\mathrm{m}_{\max }} \mathrm{nm}$ & $\Delta S, \quad$ n⿴囗十 & $\Phi$ & ${ }^{a b s_{\lambda_{\max }}}$ nnt & $c m_{\lambda_{\max }}, \quad n m$ & $\Lambda S, \quad$ nm & (b) \\
\hline Cyan 1 & 417,435 & 503 & 68 & 1.2 & 417,437 & 492 & 55 & 1.9 \\
\hline Cyan 2 & 454,520 & 534 & 14 & 3.0 & $\approx 480$ & n. d. & n. d. & n. $d$. \\
\hline Cyan 3 & 429,444 & 496 & 52 & 160.0 & 427,450 & 494 & 44 & 350.0 \\
\hline Cyan 4 & 370,481 & 635 & 154 & 5.0 & 370,495 & 625 & 130 & 6.0 \\
\hline Cyan 5 & 485,508 & $\$ 43$ & 35 & 28.1 & 485,508 & 541 & 33 & 16.0 \\
\hline Cyan 6 & 492,515 & 536 & 21 & 800.0 & 492,515 & 536 & 21 & 1550.0 \\
\hline TO & 490,508 & 534 & 26 & 900.0 & 490,508 & 542 & 34 & 1750.0 \\
\hline
\end{tabular}

n. d. - values are not detected under used dye concentration.

shift (154 nm for DNA and $130 \mathrm{~nm}$ for RNA). The $\lambda^{\text {abs }}$ and $\lambda^{\mathrm{em}}$ of NA - dye complex for both DNA and RNA were similar for all dyes.

As shown in Figure, the absorption spectra for the Cyanes 5, 6 and TO change by similar mode upon binding with nucleic acids. For Cyan 3 and Cyan 4 spectra mode are changing too.

Discussion. The cyanine dyes have high extinction coefficient (approaching or more than $10000 \mathrm{M}^{-1} \mathrm{~cm}^{-1}$ ) and moderate quantum yields with $\lambda^{\text {abs }}$ ranging

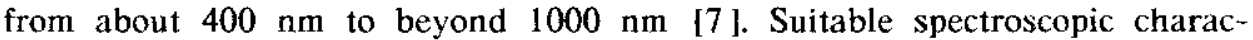
tcristics of cyanine dyes can be used to design new highly specific and sensitive fluorescent probes for different types of the nucleic acids.

All monomethyne cyanine dyes, presented in this article, contain benzothiazole fragment. Dyes have cationic character due to the delocalized positive charge of the chromophore. The spectral properties of cyanine dyes studied are only slightly sensitive to solvent changes (Table 1). In aqueous solution, all seven dyes are virtually non-fluorescent. Therefore quantum yeilds was determined only for two dyes: Cyan $1(\phi=0.0116)$ and Cyan $3(\phi=\ldots$ $0.0044)$. The Stokes shifts, demonstrated by the free thiazolc dyes $(40-79 \mathrm{~nm})$ far exceed the typical shifts, noted for cyanine dyes $(15-20 \mathrm{~nm}$, [2]). The extremely large Stokes shift $(139 \mathrm{~nm})$ for TO [1] was not determined under the used concentrations. The large Stokes shifts for free dyes can be explained by the tendency of the dyes to form dimers in water.

Complex formation of dyes with DNA and RNA results in increasing of the fluorescence quantum yield (Table 2). Cyan 3 and Cyan 6 have shown the highest fluorescence enhancement upon interaction with DNA and RNA. It is interesting, that Stokes shifts demonstrated by most of the bound dyes (26$154 \mathrm{~nm}$ ) far exceed the typical ones noted for DNA - dye bounded forms [2]. 
The comparison of absorption spectra for free and bound Cyan 6 and TO, showed decrease of aggregated forms of dyes upon the interaction. It confirmed a proposed intercalation mode of NA - dyes interaction (Figure).

The forms of absorption spectra profiles for Cyan 3 and Cyan 6 after mixing with NA solution were not changing from 5 minutes till two hours. It seemingly indicates a rapid NA - dye complex formation.
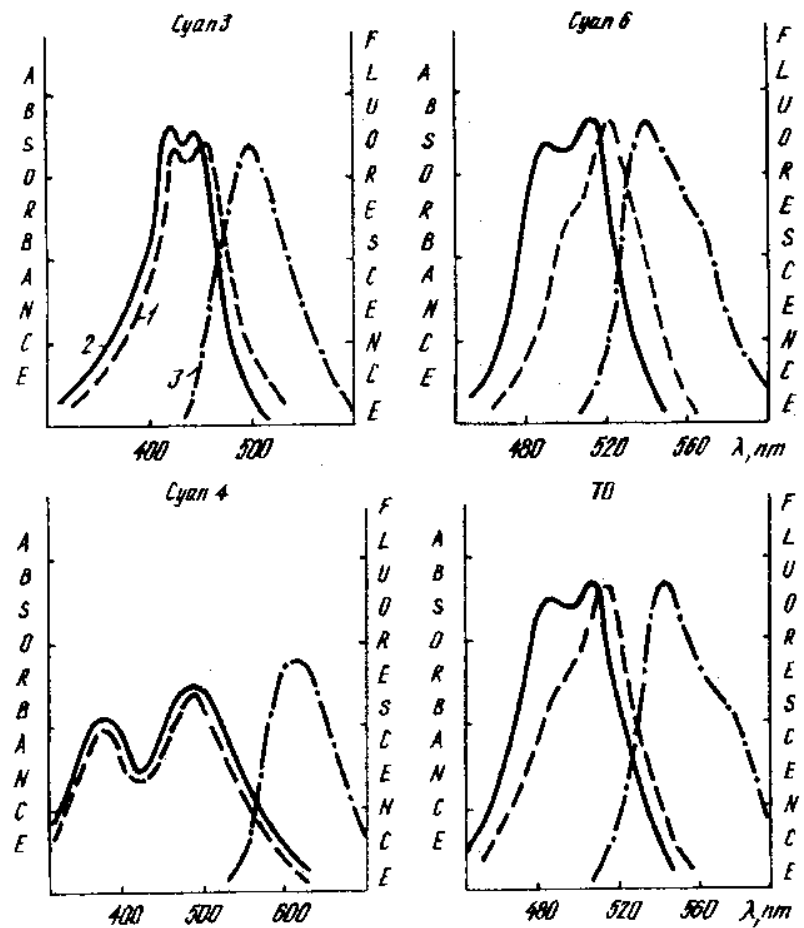

Absorption spectra profiles of free dyes and absorption and fluorescent emission spectra profiles of DNA - dye complexes in TE: absorption patterns of free dyes $(1)$, absorption $(2)$ and the fluorescent patterns (3) of DNA - dye complexes

We assumed that methylenoxybenzthiazole fragment of Cyane 3 shows the quite perspective spectroscopic properties. Therefore, the series of monomethyne cyanines with methylenoxybenzthiazole residues is being synthesized and will be under investigation.

Acknowledgements. Authors are grateful to Dr. Igor Dubey for the critically reading of the manuscript.

The project is supported by National Academy Science of Ukraine.

С. М. Ярмолюк, О. М. Живолуп, В. Б. Ковальська, Л. В. Клименко, О. Р. Кухаренко, К. П. Ковтун, Ю. Л. Сломінський

Ціанінові барвники та нуклейнові кислоти. 1. Вивчення монометинових ціанінових барвників як можливих флюоресцентних зондів для детекціт нухлеїнових кислот

Резюме

Лосліджено спектральні характеристики семи синтезованих монометинових иіанінів як можливих флюоресцентних зондів, специфічних до нуклеїнових кислот (HК). Два барвники Суап 3 та Суапб у комплексі з НК значно підвищували власну флюоресценцію (у 160 i800 разів 3 ДНК тав 350 i 1550 разів з РНК відповідно). Суап 4 при взаємодй з НК показав аномально великий (154 нм) Стоксів зсув. Метиленоксибензтіазоловий структурний фрагмент виявив перспективні властивості для конструювання нових HK-специфічних барвників серед досліджених ціанінів. 
SFRGIY M. YARMOUUK ET AL

С. П. Ярмолюк, А. Н. Живолуп, В. Б. Ковальская, И. В. Клименко, А. П. Кухаренко, Ю. П. Ковтун, Ю. Л. Сломинский

Циањиновые красители и нуклеиновые кислоты, 1. Изучение монометиноных цианиноньх красителей как возможных флюоресцентных зондов для детекции нуклеиновых кислот

Peзrome

Исследованы спектральнье характеристики семи синтезированных монометиновых цианино как возможных флюоресцентных зондов, специфитных к нуклеиновьм кислотам (НК). Двакраситејя Суап 3 и Суап 6 в комплексе с НК значительно повышали собственную флюоресценцию ( 160 и 800 раз с ДНК и в 350 и 1550 раз с РНК соответственно). Суап 4 при взаимодегіствии С НК показаи аномально больиой ( 154 нм) Стоксов сдвиг. Метиленоксибензтазоловыи структурный фрагмент проявил перспективные свойспьа для конструирования новых НК-специфических красителей среди исследованиьх цианинов.

\section{REFERENCES}

1. I $x^{\prime} t^{2}$. G., Chia-Wuei Chen, Chui I. A. Thiazole Orange: A New dye for reticulocyte analysis // Cytometry.-1986.-7.-P. 508-517.

2. Rye H. S., Yue S., Wemmer D.E. et al. Stable fluorescent complexes of double-stranded DNA with bis-intercalating asymmetric cyanine dyes: properties and applications // Nucl. Acids Res. $-1992,-20$, N 11.-P. $2803-2812$.

3. Ry\% II. S., Glazer A. N. Interaction fo dimeric intercalating dyes with single-stranded DNA //Ibid.-1995.-23, N 8.-P. 1215-1222.

4. Lursson A., Carlsson Ch, Jonsson M., Albinson B. Characterization of the binding of the fluorescent dyes YO and YOYO to DNA by polarized light spectroscopy // $\mathrm{J}$. Amer. Chem. Soc. $-1994-116$. P. 8459-8465.

5. Jacobsen J. P., Pedersen J. B., Hansen L.F., Wemmer D. E. Site selective bis-intercalation of a homodimeric thiazole orange dye in DNA oligonucleotides // Nucl. Acid́s Res. $-1995 .-23$, N 5.-P. 753-760.

6. Ernst L. A, Gupta R. K, Mujumdar R. B., Waggoner A.S. Cyanine dye labelling reagents for sulfhydryi groups // Cytometry. $-1989 .-10 .-$ P. 3-10.

7. Ииенко А. А. Строение и спехтрально-люминесцентные свойства полиметиноных красителей. - Киев: Наук. думка, 1994.-231 с. 